\title{
Anthós
}

6-2009

\section{Tax Competition in the Film Industry}

Chelsea Villareal

Portland State University

Follow this and additional works at: https://pdxscholar.library.pdx.edu/anthos

Part of the Film and Media Studies Commons, and the Taxation Commons Let us know how access to this document benefits you.

Recommended Citation

Villareal, Chelsea (2009) "Tax Competition in the Film Industry," Anthós: Vol. 1: Iss. 1, Article 4.

https://doi.org/10.15760/anthos.2009.54

This open access Article is distributed under the terms of the Creative Commons Attribution-NonCommercialShareAlike 4.0 International License (CC BY-NC-SA 4.0). All documents in PDXScholar should meet accessibility standards. If we can make this document more accessible to you, contact our team. 
Chelsea Villareal

Professor Clucas

Political Science $431 \mathrm{U}$

21 February 2009

Tax Competition in the Film Industry

Being one of the largest industries in the world, the film industry remains an economic powerhouse in our society. It's for this reason that film's messages are not the only political aspects of their creation. Senators and representatives across the country are increasingly seeing the film industry as key towards economic development. With incentive packages being placed around the country, the politics over the film industry have become an overwhelming power game. Politicians are being threatened with recalls and impeachment to keep their economies afloat during harsh economic times. Without raising taxes, representatives have hit a wall. Increasing debt and job shortages, in our current economy, are leading politicians to the West for economic growth. Whether film is considered a piece of art or a commercial product, state and local governments are looking West with Hollywood as the possible answer.

There are many general fiscal tools that are used to propel a possible increase in state revenues. There are three primary means of creating state revenues: tax revenues, intergovernmental revenues, and insurance trust revenues. With a greater emphasis on tax revenues, in Mark Crain's book Volatile States Crain states that, "Regarding tax revenues states rely largely on three instruments: general and selective sales taxes, individual (or personal) income taxes, and corporation net taxes" (Crain, 50). With a general mix of the three accounting for the base of their tax revenue, state representatives have to determine their state fiscal policies, while, all along, keeping their constituents in mind. The trend has been towards state sales tax; many states are becoming uniform in their ideals of 
generating tax revenue by looking at state income tax as a major possibility, while corporate net taxes, generating a small amount of tax revenue for states, have remained at the wayside. According to Crain, "By 2010, the typical state will raise most of its tax revenues from the individual income tax" (Crain, 63). Though many of the changes towards personal income tax have remained regressive, there are still instances of progressive change.

As well, states can also focus on state and local business taxation and property taxes as possibilities to further create tax revenue. Pogue refers to a "business tax" as: "any tax on a business's purchase of inputs, its ownership of assets, its earnings, or its right to do business" (Pogue, 89) Taxing businesses creates a larger tax base for representatives to tax without generating population uproar. Taxing business has been seen as an efficient resource allocation in terms of internalizing social costs and in supplementing direct taxes. By taxing businesses state and local governments will be able to hold businesses accountable for unpriced inputs of governmental services and negative externalities, such as environmental damage. However, there still remain struggles to carry out uniform tax policies to create the optimal outcome for corporations to create products the most efficient and cost-effective way. While taxing companies in relation to their social costs, being the negative externalities a company emits towards the general populace through their business practices, different states levy taxes in order to propel economic growth in their states, leading to tax competition. According to Pogue, "Whether or not state and local governments implement new taxes and fees to internalize social costs, they could broaden the bases of existing business taxes, especially corporation income and business property taxes" (Pogue, 105). With a proposed 
uniformity between neighboring states, states will be able to propel stronger economic growth at an optimal level.

Creating further tax revenue, property and sales tax also remain another fiscal possibility for state and local governments. However, with the increasing use of sales-tax, property taxes have become less desirable to constituents. The lump sum property taxes put excessive pressure on residents to pay their taxes at stressful "all at once" intervals. It is because property and income taxes are so bulky that government officials become targets of unwarranted regressive taxing, leading to unhappy constituents. With income taxes becoming a bigger player in the tax resource picture, residents are beginning to become touchy on tax increases, resulting in tax initiatives such as Proposition 13 in California. According to Beamer from his text Creative Politics, "If legislators can hide or obscure tax burdens by shifting from obvious 'lumpy' property taxes to less hidden, incremental sales and business taxes, they may create the perception of higher benefit/tax ratios when in reality they have only obscured a portion of the tax denominator" (Beamer, 14). Many constituents look at the increasing income taxes in reference to what's wrong with the federal government, thus many voters are looking to sales taxes as their primary means for tax revenue. However, even with this change in the fiscal market, voters still remain hesitant to allow tax increases. Many tax-paying citizens don't feel comfortable with even the most marginal of tax hikes. Tax-payers then look towards tax revolt as a possible means to influence these tax policy changes from occurring.

State and local representatives have come up against a wall. Increasing tax revenue is no longer a popular means to provide services to their district. Most taxes, income, property, and sales are seen by certain voters as regressive, depending on what 
side of the political hill they're coming from. David Super examines taxes in their cyclical relation to the economic cycle of boom and bust. "Precisely because property taxes continue to extract similar amounts even after a recession has reduced many owners' ability to pay, they have taken the brunt of taxpayers' revolts" (Super, 369). As well as dealing with regressive taxes such as the property tax, many states are dealing with governments that are "overspending" their budgets on public projects and towards public funds. Many constituents want to see their money returned to them through tax rebates and will settle for less money being allocated to "unneeded" public policies that only given benefits to certain groups of the population. Taxes have become associated with corrupt governments and overzealous legislatures that control purse strings. Thus, voters are beginning to propose tax revolts, when legislatures overspend on issues that help the commonwealth in general, but not their specific needs.

TEL's or Tax and Expenditure Limits, which limit governmental taxes and spending limits, have been recognized as a stronger tool for direct democracy in many states across the nation. Voters create initiatives limiting state budgets on specific revenues, mostly tax, to keep the legislature from spending their money. Though theoretically a healthy idea for spending containment, most TELs have shortcomings and loopholes. Among them, California's "Gann Limit" legislature spending limit is probably the most infamous. "Proposition 4, the 'Gann limit,' passed in 1979 as a part of the state's famed tax revolt and established formula limiting the growth of expenditures of tax dollars" (Kousser et. al., 290). Led by Paul Gann, a co-sponsor of previous tax propositions, the tax revolt was initiated by a private group, "The Spirit of 13, Inc.," who collected over 900,000 signatures, a hugely significant amount for any tax revolt, to 
openly prohibit the Californian State Legislature from freely spending excess amounts of community revenue. Though infamous because of the tax-payers' massive cooperative action to rescind their legislatures' budget power, Kousser argues that the Gann Limit did not constrain growth of state government, because legislators have used their powers to circumvent limitations in the details of thousand-page budget papers. Eventually, the Gann Limit became a dead issue because it did not limit nontax revenue and state legislatives continued to spend money through debt and user charges and fees of state institutions. "By turning to alternate sources of revenue, such as debt and user charges, lawmakers are able to undermine the spirit of the tax-revolt era and spend freely" (Kousser et. al., 308). California's increasing debt burden caused more problems than many foresaw.

State constituents want to continue their economic growth. With growing populations, states are beginning to index towards inflation and population leading to further public spending, thus reflecting the inefficiencies of Tax and Expenditure Limits. Thus, even initiatives are reaching past constituent control, their effectiveness depending on the political environment and the ideological patterns of their lawmakers. Even with a budget policy under electorate control, governmental officials are still finding the means to spend money, whether by means of the people's resources, or by spending money that they don't have. Despite the recognition of TELs, their success remains directly on whether politically environments are fiscally conservative, not needing the limits in the first place. This leads lawmakers and constituents back to where they began, trying to find a way to compromise on reduced spending, while giving the public all that it wants. 
So, what is a governmental official to do? Lawmakers are constantly facing the battle of where to get the resources for the public's needs. Legislators are dealing with the Tax-Service Paradox, essentially meaning that constituents don't want to get taxed higher rates and yet want more public services. During fiscal crisis, this has led lawmakers to look for new and innovative ways to regain resources during their economic collapse. According to Steven Gold, "Currently a great deal of interest has been stimulated by the book Reinventing Government, which urges that state and local governments adopt numerous reforms such as decentralizing, privatizing, deregulating, becoming more enterprising, and reforming budget to make it results-oriented rather than input-oriented" (Gold, 46). Though most of these reforms aren't new by any means, they provide states with the harsh possibilities of dealing with recent fiscal crises including cutting spending and short term benefits, increasing revenue by increasing their tax base, and through gimmicks, which merely shift costs to a later period. Many state and local governments have and are looking to reform to help stabilize and promote economic growth in their jurisdictions. According to Gold, "In terms of spending, reforms may try to implement some of the reinventing government themes, or they may reorient budget priorities. In terms of taxation, reforms may aim to make the tax system more fair or favorable to economic development or to increase the neutrality, stability, or elasticity of the tax system" (Gold, 48). Though reforms are categorized differently, based on the political culture of the state that can be used to promote growth, they still leave lawmakers in constrained situations. Gold also mentions that these reforms are not exhaustive and though many state governments try to initiate reforms without angering their electorate, they suspend these reforms because of their policy constraints through direct democracy. 
This leads them to increase their budgets through debts and deficits, keeping their spending constant and their short term economy stable, all the while keeping the future in the dark.

In order to keep states from being in the dark, law makers look to new abstract and obscure strategies to keep their economies afloat and create future growth. One strategy that states employ to promote economic growth, as well as competition with each other, is tax competition. "Among the most prominent features of state policy in recent years has been the proliferation of tax provisions designed to improve the state's business climates and to enhance their ability to attract and retain business investment and the associated jobs" (Enrich, 73). Most scholars argue that tax competition thwarts the national economic success and benefits sole states. As well, tax incentive packages are a high risk when states expect to make back their tax incentive revenue through the business after the business has developed in their area.

Tax competition is believed to intensify in upcoming years, leading to more interstate commerce. Tax abatements, and credits for expansion for car manufacturers and other commodity companies are getting past the Constitution's Commerce Clause, in which Congress has the power to regulate commerce with foreign nations, between states, and with the Native American tribes. Peter Enrich argues that this is simply because no case has been brought to the Supreme Court in order to challenge the unconstitutionality of tax competition. Therefore, with tax incentives increasing throughout state governments, state and local officials are facing the classic prisoner's dilemma, a form of game theory in which one player's success in making choices depends strictly on the choices of others. Thus, the optimal outcome for each state, the player, in which both 
states receive the most benefited outcome possible, would be to have zero tax incentives. But fairing constituent pressure to "do something" for economic growth, state law makers are still wrapped up in competition for businesses, thinking that every business attracted and located in their state will be the exception. As Enrich describes, "In this environment, it is very hard for a political leader to oppose highly visible measures that vocal business representatives assert will improve the states" "business climate" and help to attract or retain jobs" (Enrich, 77). And what industry would influence political leaders more than the stabilized "recession-proof" American Film Industry?

"Motion pictures, meeting at popular prices, the universal demand for recreation and amusement, have quickly become an essential part of modern living" (Halsey, Stuart \& Co., 195). The lucrative profiting behind the Film Industry is well known to policy makers across the nation. Since the beginning of the $20^{\text {th }}$ century, film moguls have been making their impact on the rest of the nation. However, it wasn't until the studio system that the film industries became well-oiled machines. What's significant about the film industries' success is that it occurred when the rest of the country was suffering from the Great Depression, running dry with debt and hunger. Films provided escapist comedies and dramas that helped many cope with the economic down turns of the country. The studio systems' success promoted huge economic growth for California during the Great Depression. Since then, and with the invention of the genre system, a film production system which promotes the familiarized and financially predictable genre films such as romantic comedies or slasher horror films, business men and policy makers alike have looked to the Film Industry, as a sure medium of financial growth. However, the 
difficulty in convincing the industry to invest in local and state economies has been relatively difficult.

"The great concentration of film production within that small geographical area is a distinctive of this industry" (Halsey, 200). Although Hollywood is a unique local dream factory to Californians, since globalization the possibilities of transferring the film industry to foreign markets as well as different state markets have been a central motive to film investors. Primarily, seeing where producers can produce a film the cheapest and where the film incentive packages are the best remains the key factor in film production. These film productions would not only produce jobs and investment to state economies, but it would provide a state exposition to the rest of the nation, encouraging further growth through tourism. This financial strategy would keep constituents interest not only because they're not paying higher taxes but because the dreams of Hollywood are being made in their backyard.

"The MPAA (2004) estimated that in 2001, the U.S. entertainment industry had more than 700,000 total employees and contributed $\$ 41$ billion in expenditures to the U.S. economy" (Litvak, 281). From Litvak's research, it's conclusive that the states with the highest impact in this area are California with New York trailing in a far second. Runaway production of films to cheaper states has been occurring since the break down of the studio system in the 1960's. Once located solely in California, projects are being moved not only to different states but to different countries, leading in this trend is Canada. Many economic officials argue, as before, that the tax competition between states for film industry production is clearly a risky one, considering that the film products are not everlasting and occur only as long as the production is on location. 
Regardless, film commissioners eager to settle and get a film going easily persuade policy makers to become part of the prisoner's dilemma. It seems as if the cycle is ongoing, and with the increase of low-production indie films and television series as a main component of major film studio audience attractions, it is no wonder the competition is sky-rocketing.

According to Litvak, "The average major Hollywood feature picture has a production budget of approximately $\$ 60$ million, and about $33 \%$ of the budget is generally spent on location. Between 1994-2004, the average cost of production by Hollywood majors increased from $\$ 34.3$ million to $\$ 63.6$ million” (Litvak, 282). Thus, film commissions are getting more and more eager to attract investors and policy makers are becoming more easily persuaded to enact tax incentive packages in order to do so. Given this, states are now using new media as a way to persuade film production companies to come their way. For example, Georgia's film commission presents overtly on their website, "On May 12, 2008 Governor Sonny Perdue signed into law the Georgia Entertainment Industry Investment Act, boosting the state tax credit for qualified production and post-production expenditures by as much as 30\%" (Georgia Film Commission Website). As well, Georgia's film commission places the application for production openly on their website, encouraging new and innovative industries, such as gaming and animation.

Texas' Film Commission and Office of the Governor website promotes its production incentives of "a payment equal to $5 \%$ of eligible in-state spending, including wages paid to Texas residents, upon completion of an audit of Texas expenditures" (Texas Film Commission Website). Texas also places their rules and regulations on their 
website a minimum of a million dollars in in-state spending, having eighty percent of the production completed in Texas, seventy percent of paid crew be Texas residents as well as the cast and extras. The Texas Commission also provides further in-state spending incentives, if film productions use unused areas, such as areas around Austin and Dallas City Hall. Further, Texas keeps certain productions from gaining any production support. These projects are defined clearly as reality television shows, pornography, and pieces as odd as casino-type video games.

According to Utah's Film Commission website, the governor provides "a postperformance rebate of production dollars spent in the state of Utah. An approved production will be rebated $15 \%$ on every dollar spent in the State of Utah. A production must spend a minimum of $\$ 1,000,000$ in the state to qualify" (Utah Film Commission Website). As well, Utah's Film Commission offers the resources of federal, state, and city and county agencies, in order to help production companies with their location shootings. Such agencies include Governor's Office of Economic Development, Utah Office of Tourism, National Parks Services, and the Department of Defense.

Going local, as California is trying to keep films from leaving its indebted economy, Oregon, is boasting greener pastures to the North: "Our incentive programs rebate $20 \%$ of your Oregon-based goods and services, and an additional cash payment of up to $16.2 \%$ of wages paid to production personnel" (Oregon Film Commission Website). The Oregon's Film Commission claims that unlike most other states, film producers will get cash rebates instead of credits for their business. Also, Oregon uses it's no sales tax policy as a further incentive and will even do a comparative budget analysis against other states. As well as no sales tax, Oregon provides further savings of fee-free state parks, 
counties, and cities, hotel discounts, waived lodging taxes, and dual marketing for casting (Oregon Website).

Whether considered a Film Office, Commission, or Bureau, all states have them. As shown above, tax incentive competition has become a marketing ploy used in order to hook investors with each film trying to "out-state" the other. States are in fact attracting different blockbuster films such as Tyler Perry Studios’ Madea Goes to Jail (Tyler Perry, 2008) in Georgia, Crystal Lake Entertainments' Friday the $13^{\text {th }}$ (Marcus Nispel, 2009) in Texas, Disney's High school Musical 3: Senior Year (Kenny Ortega, 2008) in Utah, and Laika Entertainment's Coraline (Henry Selick, 2009) in Oregon. So clearly, the incentive packages are working to relocate films from Hollywood to the rest of the country. However, Hollywood is still the general foundation from which most dreams come true. But the general question to be pursued is "now what?" As mentioned before, scholars argue that tax competition between states is not only detrimental to the national economy, but is unconstitutional. The projects are short term and the location-shoots are only temporary. The industry is footloose and more companies, independent and local, are contributing to propel growth in the industry. Regardless of locally based productions, the big budget films are still in Hollywood. With this in mind, we look to Peter Enrich, who argues, "business tax policy will be driven by tax competition, which will become more aggressive as business mobility, national and international, increases" (Enrich, 105).

As films are still strongly seen as Hollywood-oriented, it's important to look at the source of the interstate competition: Hollywood itself. States depend on the artistic qualities and quantities of technological and human capitol in California. This is why it's unnerving to find that Hollywood, in this time of severe recession, is being cut from 
national stimulus package. According to The New York Times, "Senator John McCain joined Senator Tom Coburn in opposing a provision that would give the film industry additional help. Senator Max Baucus contended the item would benefit independent, small filmmakers. The Senate voted 52-45 to strip the provision out of the package" (Phillips). Even though Hollywood is being said to be "doing okay," the question of how this is going to hit state film commissions and local film markets couldn't be far from negative. The trickle-down effect should only get worse, before it gets better. It appears that federal senators have their eyes strictly on Hollywood and aren't looking at the interstate commerce competition that has developed around it.

It's clear that film genres, such as musicals and comedies, have propelled not only the human psyche through difficult times in our economy. Despite the fact that scholars denounce interstate tax competition, it's still present and it doesn't appear to be slowing down. States are using the film industry to propel economic growth in their economies. Locals aren't paying higher taxes and many are getting production jobs on set. Film Commissioners are promoting their states as advertisements on the silver screen across the nation when audiences watch films with their state landscapes in the background. However, even if the success is short-term, at least it's providing some strategy for governors and law makers. Some of these short-term productions are creating interest in the local sectors to create their own studios to further long term growth in their cities and counties. Escapist films during economic hardships provide audiences with the emotional basis to propel their economies out of recessions. Nonetheless, with a reduced subsidy package for Hollywood, the future remains ambiguous. 


\section{Work-Cited Page}

Beamer, Glenn. Creative Politics: Taxes and Public Goods in a Federal System. United States of America: The University of Michigan Press, 2002.

Crain, W. Mark. Volatile States: Institutions, Policy, and the Performance of American State Economies. The United States of America: The University of Michigan Press, 2006.

Enrich, Peter D. The Rise- and Perhaps the Fall- of Business Tax Incentives. Ed. David Brunori. Washington D.C.: The Urban Institute Press, 1998.

Gold, Steven D. A Framework for Viewing State Policies. Ed. Steven D. Gold. Washington D.C.: Georgetown University Press, 1995.

Halsey, Stuart \& Co. The American Film Industry: The Motion Picture Industry as a Basis for Bond Financing. Ed. Tino Balio. The United States of America: The University of Wisconsin Press, 1985.

Kousser, Thad et. al. When Does the Ballot Box Limit the Budget?: Politics and Spending Limits in California, Colorado, Utah, and Washington. Ed. Elizabeth Garrett, Elizabeth A. Graddy, Howell E. Jackson. United States of America: Cambridge University Press, 2008.

Litvak, Isaiah A. Hollywood Movie Production Industry: Floating Factories. Proceedings- AIB-SE (USA) 2006 Annual Meeting: Clearwater Beach, Fl. 25 Feb. 2009.<http://www.aibse.org/Proceedings/Proceedings\%202006/28\%20Litvak,\%2 OLitvak.pdf $\$$.

Oregon Film: Governor's Office of Film and Television. 1 Mar. 2009. $<$ http://oregonfilm.org/incentives/savings/ $>$.

Phillips, Kate. "Stimulus in the Senate: P.M. Update." New York Times

3 Feb. 2009. 25 Feb. 2009.

$<$ http://thecaucus.blogs.nytimes.com/2009/02/03/stimulus-in-the-senate-pm-

update/>.

Pogue, Thomas F. State and Local Business Taxation: Principles and Prospects. Ed. David Brunori. Washington D.C.: The Urban Institute Press, 1998.

Texas Film Commission: The Office of Governor Rick Perry. 1 Mar. 2009. $<$ http://governor.state.tx.us/film/incentives/miiip/ >.

Utah Film Commission: Motion Picture Incentive Fund. 1 Mar. 2009. $<$ http://film.utah.gov/mpif.htm $>$. 
Welcome to Georgia Incentives. 1 Mar. 2009.

$<$ http://www.georgia.org/EntertainmentIndustry/AboutTheIndustry/Incentives.ht $\mathrm{m}>$. 